\section{Neuropsychology and malnutrition: a study with 7 to 10 years-old children in a poor community}

\section{Neuropsicologia e desnutrição: um estudo com crianças de 7 a 10 anos de idade, em uma comunidade carente}

Mônica C. Miranda1

Fernando J. Nóbrega2

Kazue $\mathrm{Sato}^{3}$

Sabine Pompéia ${ }^{4}$

Elaine G. Sinnes 5

Orlando F.A. Bueno 6

1,4-6 Departamento de Psicobiologia. Universidade Federal de São Paulo. Rua Embau, 54. São Paulo, SP, Brasil. CEP: 04.039-060. E-mail: mcarol@psicobio.epm.br. Phone: 5511 5549-6899/5549-5496; Tel: 5511 5572-5092.

2,3 Programa Einstein de Nutrição na Comunidade de Paraisópolis. Paraisópolis, São Paulo, Brasil.

\section{Resumo}

Objetivos: comparar o perfil neuropsicológico de crianças eutróficas, desnutridas pregressas e crônicas, em idade escolar, e analisar o papel de fatores, socioeconômicas, no seu desenvolvimento cognitivo.

Métodos: foram avaliadas crianças de ambos os sexos, 27 eutróficas, 31 desnutridas pregressas e 15 desnutridas crônicas, de 7 a 10 anos de idade, de uma comunidade carente da cidade de São Paulo. A avaliação incluiu funções cognitivas pouco investigadas nessa população; memória operacional, memória declarativa e não-declarativa, atenção e funções executivas. Foram analisados também condições socioeconômicas, saúde mental materna e comportamento na escola.

Resultados: as crianças desnutridas crônicas tiveram pior desempenho do que as eutróficas no teste de vocabulário $\left(p_{s}<0,05\right)$ e no teste de memória operacional vísuo-espacial $(p=0,01)$, mostraram-se mais ansiosas $(p=0,006)$, somente dois indivíduos tinham desnutrição pré-natal. As crianças desnutridas pregressas não mostraram prejuízos. Nas variáveis socioeconômicas não houve diferenças.

Conclusões: a desnutrição crônica foi relacionada a prejuízo de linguagem expressiva, memória operacional vísuo-espacial e maior ansiedade. Não houve prejuízo de nível intelectual, funções executivas, memória de longo prazo e função vísuo-construtiva. A preservação da maioria das funções cognitivas pode ser atribuída à ausência de desnutrição intra-uterina, elou ao fato de que, as crianças vivem em adequado ambiente socioeconômico.

Palavras-chave Desnutrição, Testes neuropsicológicos, Neuropsicologia 


\section{Introduction}

Malnutrition is one of the principal problems in the world's Public Health Sector, especially in underdeveloped and developing nations. It is considered to be a disorder associated with poverty, lack of access to economical, educational and health resources of high risk groups. ${ }^{1}$ In recent years there has been an increase in the awareness of the significance of malnutrition in the development of the Central Nervous System (CNS). It is postulated that permanent effects of malnutrition are found in brain morphology, physiology and neurochemistry, and that these may have implications to behavioural and cognitive development.2,3 Malnutrition does not occur independently from environmental conditions; several factors have been identified that could interfere in the child's capability to respond appropriately to the environment, such as inadequate socioeconomic conditions, undereducated parents, family problems, as well as reduced environmental stimulation. 4

The studies investigating the effects of malnutrition on cognitive development report controversial data. For example, various have found that severe post-natal malnutrition negatively influences the development of functions such as intelligence, memory, verbal abilities, problem solving capability and motor development.5-10 Other studies ${ }^{11}$ showed none of these effects, but found motor and perceptual impairments. Likewise, no detrimental effects in abilities such as arithmetics, visual functions and attention 8,9 have been found, nor in Intelectual Quocient, although it seems to decrease according to the degree of malnutrition. 10

More recent studies have also attempted to investigate the role of other factors usually associated with malnutrition in cognitive impairment. Probably the most important of these is low birth weight, which is observed in lower socio-economic classes and is related to maternal conditions during gestation such as specific pathologies, age and maternal malnutrition. Some studies have shown that low birth-weight has major influence in the development of functions such as memory, mental flexibility, lateral thinking, perceptual motor abilities, reading and mathematics tests 12,13 despite the fact that although the characterization of intra-uterine malnutrition based solely on newborn weight has been extensively used, it can be considered an insufficient criterion for such. ${ }^{14}$ Other key factors in cognitive development such as hospitalization, prolonged episodes of diarhoea and infections have also been associated with larger impair- ment. 7,8,10,11,12,15,16 In addition, numerous studies suggest that socio-economic status seems to be an important factor for understanding the effects of malnutrition in cognitive behaviour. The risk of malnutrition may also be associated with maternal mental health, unstable family structure, poor education, unemployment, low income, and inadequate living conditions. ${ }^{17-20}$ Some of these factors significantly influence the cognitive performance of children with pre-uterine, intra-uterine and postnatal malnutrition. 10-13,21

In sum, several studies have attempted to elucidate the role of malnutrition on cognition but "despite extensive efforts, it continues to be uncertain whether cognitive impairment is an inevitable consequence of malnutrition",22 as well as which cognitive functions, if any, are permanently affected. In studies with human beings discrepancies between studies arise from differences in the length, severity, time and type of malnutrition, 6 but probably more so due to difficulties in isolating the effects of malnutrition from economic, social and cultural factors, in addition to the use of a wide variety of tests to evaluate cognitive functions. The latter issues would be minimized by using a test battery with a sound theoretical basis as proposed by developmental neuropsychology. 23

The objective of the present investigation was to study the cognitive effects of malnutrition comparing the neuropsychological profile of eutrophic, stunted and chronically malnourished 7to 10 -year-old children. More specifically the study aimed at verifying the development of functions that have not been explicitly studied before using developmental neuropsychology as a basis for selecting tests, which included measures of different subtypes of memory (working, declarative and non-declarative memories) taking into account other potential factors known to alter cognitive development, such as birth weight and environmental variables.

\section{Methods}

The children were selected using the following procedure: the weight and height of 562 six- to tenyear-olds of the public school system in the second poorest community of São Paulo City were measured. The height/age (H/A) and weight/height $(\mathrm{W} / \mathrm{H})$ indicators were calculated on Epinut by EpiInfo, version 6.04, using the Waterlow classification modified by Batista.24 Among all children, 45\% were eutrophic, $20 \%$ were stunted and $5 \%$ were chronically malnourished. Children with acute 
malnutrition were not assessed in this study. The remaining children, 47 eutrophic and 47 stunted, were pseudorandomly selected according to age and gender for the purpose of groups' assessment.

Considering that the number of chronically malnourished children was much lower, all 29 of 7to 10 -year-olds with this condition were included. Parental refusal and children fitting the exclusion criteria (neurological disorders, current use of medication, history of domestic violence) led to the final sample of 27 eutrophic, 31 stunted and 15 chronically malnourished boys and girls.

All procedures utilised in this study were approved by the Research Ethics Committee of the researchers' institutions Universidade Federal de São Paulo in the city of São Paulo, Brazil and the Education and Research Institute at Albert Einstein Hospital. The children's parents signed informed consent forms agreeing with their children's participation.

The children were evaluated at their own school, individually. The assessment was carried out by two fully qualified neuropsychologists blind to childrens' nutrional status. The tests were carried out in 2 or 3 sessions and were applied in a random order. The following neuropsychological tests 25-27 were used:

1. Intellectual level: Raven's Coloured Progressive Matrices - Special scale.

2. Attention and Concentration: Cancellation of letters and symbol tests.

3. Executive functions: Wisconsin Card Sorting Test-WCST

4.Language: vocabulary subtest (WISC); Comprehension subtest (Stanford-Binet Scale).

5. Visual constructive function: The Bender Visual Motor Gestalt test.

6. Visual perceptual function: naming subtest (Stanford-Binet scale).

7. Long-term memory: episodic memory was evaluated with immediate and delayed recall of prose (Rivermead Behavioral Memory Test) and Bender pictures; semantic memory was tested with animal and fruit fluency tests; procedural memory through application of the Tower of London, and repetition priming through a picture fragment test. 25

8. Working memory: Corsi Block and Digit Span test; Brazilian Test of Pseudoword Repetition (BCPR). 26

9. Literacy assessment: writing, reading and mathematics tasks - abbreviated method extracted from the Educational Performance Test. 27

10. Behaviour (Teacher Rating BehaviourScale;
EACI-P) 28 which assesses 5 factors: hyperactivity, independent functioning, inattention, socialization, and anxiety;

11. Maternal mental health: SRQ-20 (Self Reporting Questionnaire, 20 item version). ${ }^{29}$

Other variables (factors not analyzed as used only for control of exclusion criteria):

a) Socio-economic and bio-psychological status: those responsible for the children filled a questionnaire which included information on:

i) number of people in the household; family income; mother's and father's background; living conditions (type of building, number of rooms) and sanitary conditions (refuse collection, water, electricity, sewage);

ii) gestational background, birth weight and hospitalizations due to infection and/or diarrhoea.

iii) data on clinical/psychiatrical diseases of children, as well as medication use.

The hypotheses of normal distribution and homocedasticity were analysed using the ShapiroWilk and Levene test, respectively. The 13 variables according to these hypotheses were compared by one way ANOVA, followed by the orthogonal contrast method in order to identify mean differences. For the remaining variables, the Kruskall-Wallis non-parametric test and multiple comparisons were used; for the sex variable, the ChiSquare test was used.

In order to study the influence of malnutrition and environmental factors on neuropsychological development, an (exploratory) regression analysis was undertaken using the indicators $\mathrm{H} / \mathrm{A}$ and $\mathrm{W} / \mathrm{H}$, gender, age, socio-economic and neuropsychological profile variables. The children included were those for which complete data were available: 36 stunted and chronically malnourished, and 19 eutrophic. Thereafter, variables significantly associated with anthropometric indexes and adjusted models of Multiple Linear Regression were selected, taking into consideration dependent variables from results of the neuropsychological assessment in this study. The independent variables considered were: group (both malnourished groups collapsed, vs. eutrophics), sex, age, birth weight, parents' education, income and maternal mental health (SRQ). The supposition of normal distribution was verified through normal graphics of probability with bands of trust. In cases showing signs of heterocedasticity, a logarithmic transformation was used for the dependant variable. In order to measure the quality of models adjustment, the explanation or determination coefficient (R2) was taken into account. In addition, following regression analysis of the neuropsychological tests in which age was associated to perfor- 
mance, an ANCOVA analysis was performed, with age as a co-variable. The significance level adopted was $p<0.05$. Statistical computer programs used was SPSS version 11.0 and proc GLM - SAS, version 8.0

\section{Results}

The groups did not significantly differ in terms of age and gender (Table 1). However, there were significant differences in the $\mathrm{W} / \mathrm{H} \mathrm{F}(2,70)=37.60$; $\mathrm{p}=0.001$ and H/A $\mathrm{F}(2,70)=65.1 ; \mathrm{p}<0.001$ reflecting the allocation of subjects to one of the three groups: the $\mathrm{W} / \mathrm{H}$ of chronically malnourished children was significantly lower than of the other two groups $\left(\mathrm{p}_{\mathrm{s}}<0.001\right)$, while the stunted and chronically malnourished children had H/A inferior to that of the eutrophic children $\left(\mathrm{p}_{\mathrm{s}}<0.001\right)$. One child in the eutrophic and one in the chronically malnourished group had birth weights under $2.5 \mathrm{~kg}$.
There were no significant differences between the groups in relation to socio-economic data, as depicted in Table 2. As for the remaining data, $100 \%$ of the sample had access to electricity, public water supply and in-house bathrooms, therefore such data was not considered when comparing groups. Statistical analysis was not carried out for results for there was no dissimilarity related to the parents' background. There were no cases of hospitalization due to infections or diarrhoea.

Significant differences were reported in regard to birth weight $\mathrm{F}(2,54)=3.78 ; \mathrm{p}=0.03$ (Figure 1), lower in chronically malnourished children when compared to the eutrophic participants $(p=0.01)$. As for the maternal mental health assessed by SRQ (Figure 2), there was a significant difference between groups $\left(\mathrm{X}^{2}(2)=8.090 ; \mathrm{p}=0.02\right)$, the mothers of the children from the eutrophic group had higher scores when compared with the other groups $(\mathrm{p}<0.03)$.

Table 1

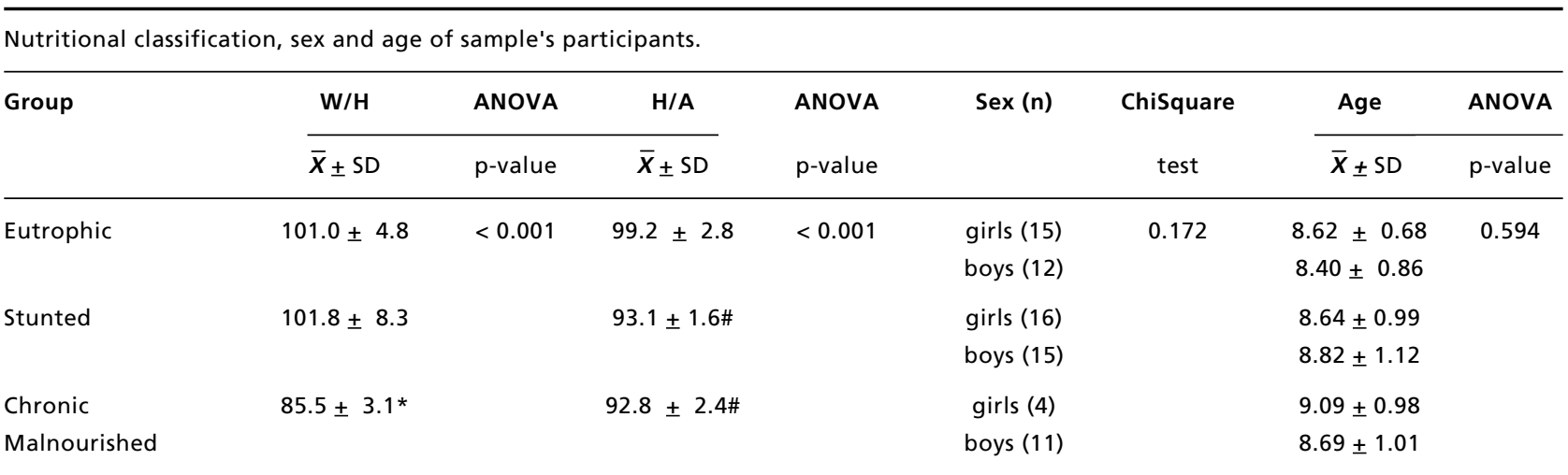

$(\mathrm{W} / \mathrm{H})$ weight for height; $(\mathrm{H} / \mathrm{A})$ height for age; $\mathrm{n}=$ number of children included in the sample; * W/H - ANOVA - orthogonal contrast method - chronic malnourished children was significantly lower than of the other two groups (ps $<0.001$ ); \# H/A stunted and chronic malnourished children: H/A inferior to the eutrophic children (ps $<0.001$ )

Table 2

\begin{tabular}{|c|c|c|c|c|}
\hline \multicolumn{5}{|c|}{ Socio-economic data of the sample's participants. } \\
\hline \multirow[t]{2}{*}{ Socio-Economic Data } & Eutrophic & Stunted & $\begin{array}{c}\text { Chronic } \\
\text { Malnourished }\end{array}$ & $\begin{array}{l}\text { ANOVA } \\
\text { p-value }\end{array}$ \\
\hline & $x \pm S D$ & $X_{ \pm}$SD & $X_{ \pm}$SD & \\
\hline $\begin{array}{l}\text { Number of people living the } \\
\text { household }\end{array}$ & $5.0 \pm 1.4$ & $5.6 \pm 2.1$ & $5.5 \pm 1.3$ & 0,466 \\
\hline $\begin{array}{l}\text { Number of rooms in the } \\
\text { household }\end{array}$ & $3.0 \pm 1.7$ & $3.5 \pm 1.3$ & $3.1 \pm 1.2$ & 0,452 \\
\hline Income per capita & $0.6 \pm 0.4$ & $0.8 \pm 0.5$ & $0.7 \pm 0.4$ & 0,611 \\
\hline Father's Education (Years) & $2.7 \pm 3.0$ & $3.1 \pm 2.6$ & $3.7 \pm 3.2$ & 0,677 \\
\hline Mother's Education (Years) & $2.9 \pm 2.0$ & $3.3 \pm 2.6$ & $3.7 \pm 2.8$ & 0,612 \\
\hline
\end{tabular}




\section{Figure 1}

Birth weight (means) in relation to the classification of groups.

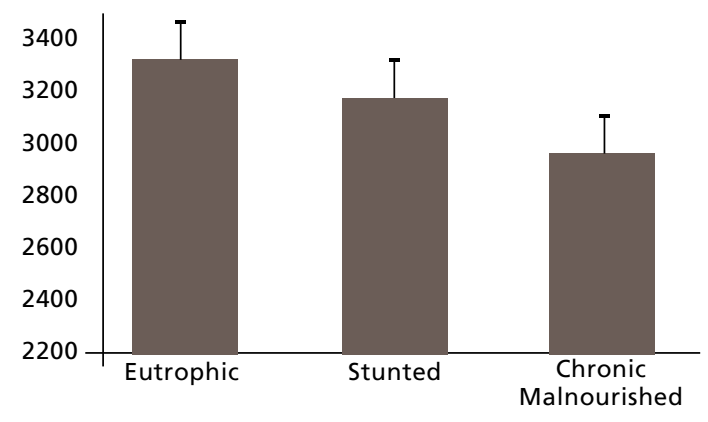

* ANOVA $F(2,54)=3.78 ; p=0.03$ orthogonal contrast method chronic malnourished $<$ eutrophic $(p=0,01)$.

\section{Figure 2}

Scores (means) of mothers on questionnaire SRQ-20 regarding the classification of groups.

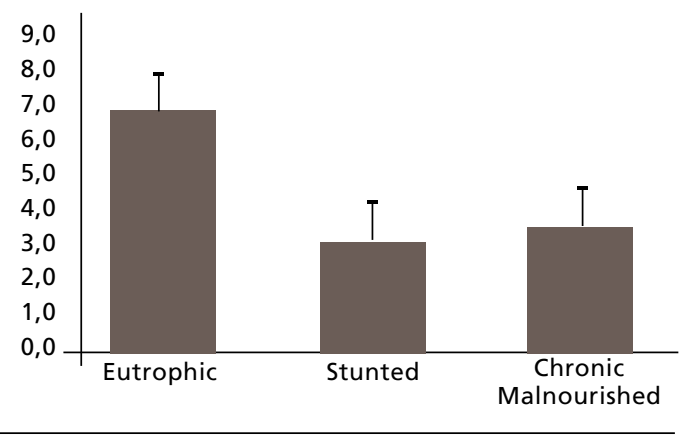

* Kruskall-Wallis $(X 2(2)=8.090 ; p=0.02)$ multiple comparisons - eutrophic $>$ stunted $(p=0.007)$ and chronic malnourished $(p=0.02)$.

\section{Table 3}

Neuropsychological evaluation tests mean values.

\begin{tabular}{|c|c|c|c|c|c|}
\hline \multirow[t]{2}{*}{ Test } & $\begin{array}{c}\text { Eutrophic } \\
(n=27)\end{array}$ & $\begin{array}{l}\text { Stunted } \\
(n=31)\end{array}$ & $\begin{array}{l}\text { Chronic Malnourished } \\
\qquad(\mathrm{n}=15)\end{array}$ & \multirow[t]{2}{*}{ Estat. } & \multirow[t]{2}{*}{ p value } \\
\hline & $\overline{\boldsymbol{X}} \pm \mathrm{SD}$ & $\overline{\boldsymbol{X}} \pm \mathrm{SD}$ & $\overline{\boldsymbol{X}} \pm \mathrm{SD}$ & & \\
\hline \multicolumn{6}{|l|}{ Intellectual level } \\
\hline Raven (percentile) & $56.4 \pm 18.6$ & $50 \pm 21.3$ & $50.3 \pm 21.4$ & ANOVA & 0,815 \\
\hline \multicolumn{2}{|l|}{ Cancellation of Letters } & & & & \\
\hline Errors & $0.0 \pm 0.00$ & $0.03 \pm 0.2$ & $0.0 \pm 0.0$ & - & \\
\hline Omissions & $2.7 \pm 2.5$ & $2.06 \pm 2.6$ & $3.9 \pm 7.2$ & $\mathrm{~K}-\mathrm{W}$ & 0.623 \\
\hline Time of execution (seg.) & $187.5 \pm 49.8$ & $194.4 \pm 51.7$ & $189.2 \pm 64.6$ & $\mathrm{~K}-\mathrm{W}$ & 0.811 \\
\hline \multicolumn{6}{|l|}{ Cancellation of Simbols } \\
\hline Errors & $2.5 \pm 4.1$ & $5.9 \pm 20.5$ & $2.4 \pm 2.7$ & $\mathrm{~K}-\mathrm{W}$ & 0.687 \\
\hline Omissions & $17.3 \pm 17.6$ & $12.3 \pm 11.4$ & $27.6 \pm 48.2$ & K-W & 0.340 \\
\hline Total Analysed & $239.2 \pm 69.6$ & $207.4 \pm 52.7$ & $288.0 \pm 221.0$ & ANOVA & 0.129 \\
\hline \multicolumn{6}{|l|}{ Executive Functions (WCST) } \\
\hline Categories Achieved & $3.8 \pm 1.5$ & $3.5 \pm 1.7$ & $3.5 \pm 1.4$ & K-W & 0.872 \\
\hline Correct Responses & $70.7 \pm 14.2$ & $64.7 \pm 13.8$ & $67.6 \pm 13.3$ & ANOVA & 0.271 \\
\hline Errors & $54.3 \pm 17.2$ & $57.1 \pm 21.5$ & $61.9 \pm 19.6$ & ANOVA & 0.481 \\
\hline Perseverative Responses & $9.1 \pm 7.9$ & $8.9 \pm 7.3$ & $8.4 \pm 6.9$ & K-W & 0.988 \\
\hline Perseverative Errors & $36.0 \pm 18.9$ & $39.2 \pm 20.8$ & $44.2 \pm 18.9$ & $\mathrm{~K}-\mathrm{W}$ & 0.208 \\
\hline Nonperseverative Errors & $18.1 \pm 10.1$ & $17.9 \pm 10.9$ & $17.7 \pm 7.9$ & $\mathrm{~K}-\mathrm{W}$ & 0.988 \\
\hline Failure to Maintain the Set & $1.1 \pm 1.2$ & $0.8 \pm 0.8$ & $1.2 \pm 1.4$ & $\mathrm{~K}-\mathrm{W}$ & 0.777 \\
\hline \multicolumn{6}{|l|}{ Language } \\
\hline Vocabulary & $24.1 \pm 4.6$ & $24.4 \pm 4.8$ & $21.0 \pm 5.4^{*}$ & ANOVA & 0.04 \\
\hline Comprehension & $5.9 \pm 0.2$ & $5.9 \pm 0.2$ & $6.0 \pm 0$ & - & \\
\hline \multicolumn{6}{|l|}{ V. Visual Constructive Function } \\
\hline Bender Test & $5.6 \pm 3.1$ & $5.1 \pm 2.9$ & $4.4 \pm 3.8$ & $\mathrm{~K}-\mathrm{W}$ & 0.340 \\
\hline \multicolumn{6}{|l|}{ Visual Perceptual Function } \\
\hline Naming & $6.8 \pm 0.3$ & $6.9 \pm 0.2$ & $6.9 \pm 0.2$ & - & \\
\hline \multicolumn{6}{|l|}{ Literacy } \\
\hline Writing & $7.4 \pm 3.5$ & $7.2 \pm 4.0$ & $6.3 \pm 4.0$ & $\mathrm{~K}-\mathrm{W}$ & 0.593 \\
\hline Reading & $7.5 \pm 2.5$ & $7.4 \pm 2.3$ & $6.4 \pm 3.1$ & $\mathrm{~K}-\mathrm{W}$ & 0.371 \\
\hline Mathematics & $3.4 \pm 1.3$ & $3.7 \pm 1.2$ & $3.6 \pm 1.2$ & $\mathrm{~K}-\mathrm{W}$ & 0.533 \\
\hline
\end{tabular}


Neuropsychological evaluation tests mean values.

\begin{tabular}{|c|c|c|c|c|c|}
\hline & $\begin{array}{l}\text { Eutrophic } \\
(\mathrm{n}=27)\end{array}$ & $\begin{array}{l}\text { Stunted } \\
(n=31)\end{array}$ & $\begin{array}{l}\text { Chronic Malnourished } \\
\qquad(\mathrm{n}=15)\end{array}$ & Estat. & p-value \\
\hline & $\bar{X}_{ \pm} \mathrm{SD}$ & $\bar{x}_{ \pm} \mathrm{SD}$ & $\bar{X}_{ \pm} \mathrm{SD}$ & & \\
\hline \multicolumn{6}{|l|}{ Memóry } \\
\hline Dígit span - Forward recall & $4.0 \pm 0.7$ & $4.2 \pm 0.5$ & $4.0 \pm 0.8$ & $\mathrm{~K}-\mathrm{W}$ & 0.367 \\
\hline Dígits span - Backward recall & $2.8 \pm 0.7$ & $3.0 \pm 0.7$ & $2.9 \pm 0.6$ & $\mathrm{~K}-\mathrm{W}$ & 0.314 \\
\hline Corsi Test - Forward recall & $4.0 \pm 0.8$ & $4.3 \pm 0.8$ & $3.7 \pm 0.6 *$ & $\mathrm{~K}-\mathrm{W}$ & 0.033 \\
\hline Corsi test - Backward recall & $3.3 \pm 0.9$ & $3.6 \pm 1.0$ & $3.3 \pm 0.9$ & $\mathrm{~K}-\mathrm{W}$ & 0.492 \\
\hline \multicolumn{6}{|l|}{ BCPR 1} \\
\hline Correct & $34.0 \pm 6.4$ & $34.6 \pm 5.6$ & $33.2 \pm 5.7$ & $\mathrm{~K}-\mathrm{W}$ & 0.421 \\
\hline Errors & $5.9 \pm 6.3$ & $5.3 \pm 5.6$ & $6.8 \pm 5.7$ & & \\
\hline \multicolumn{6}{|l|}{ Explicit Memory } \\
\hline Bender - Immediate Recall & $16.3 \pm 3.7$ & $15.4 \pm 4.6$ & $16.5 \pm 4.4$ & ANCOVA & 0.688 \\
\hline Bender - Delayed Recall & $17.2 \pm 3.3$ & $16.3 \pm 5.2$ & $16.1 \pm 5.6$ & ANCOVA & 0.791 \\
\hline Immediate Story Recall & $14.2 \pm 5.2$ & $15.3 \pm 6.2$ & $12.7 \pm 5.7$ & ANCOVA & 0.307 \\
\hline Delayed Story Recall & $12.9 \pm 4.7$ & $14.5 \pm 5.9$ & $11.8 \pm 6.5$ & ANOVA & 0.275 \\
\hline $\begin{array}{l}\text { Semantic Fluency - (Animals and Fruits } \\
\text { Implicit Memory }\end{array}$ & $16.6 \pm 5.2$ & $19.0 \pm 4.5$ & $18.7 \pm 5.4$ & ANOVA & 0,167 \\
\hline Tower of London & $26.8 \pm 3.2$ & $27.3 \pm 3.1$ & $26.0 \pm 3.1$ & ANOVA & 0.410 \\
\hline Priming- Viewed Pictures & $5.1 \pm 0.6$ & $4.9 \pm 0.6$ & $5.0 \pm 0.6$ & ANOVA & 0.829 \\
\hline Priming - Non-viewed pictures & $5.6 \pm 0.6$ & $5.7 \pm 0.5$ & $5.9 \pm 0.5$ & ANOVA & 0.251 \\
\hline
\end{tabular}

*Vocabulary - ANOVA $F(2,69)=3.19$; orthogonal contrast method:chronic malnourished < eutrophic ( $p=0.03)$ and stunted malnourished $(p=0.05) ; K-W=$ Kruskall-Wallis test; ${ }^{1}$ CPR test: only correct and erros of each group are presented. as there is no significant difference in the analysis of type of error and number of syllables; * Corsi Test - Forward recall - Kruskall-Wallis $(X 2(2)=6.80 ; p=0.03)$ multiple comparisons chronic malnourished group < stunted group $(p=0.01)$; eutrophic $=$ stunted $(p=0.123)$; chronic malnourished $=$ eutrophic $(p=0.196)$

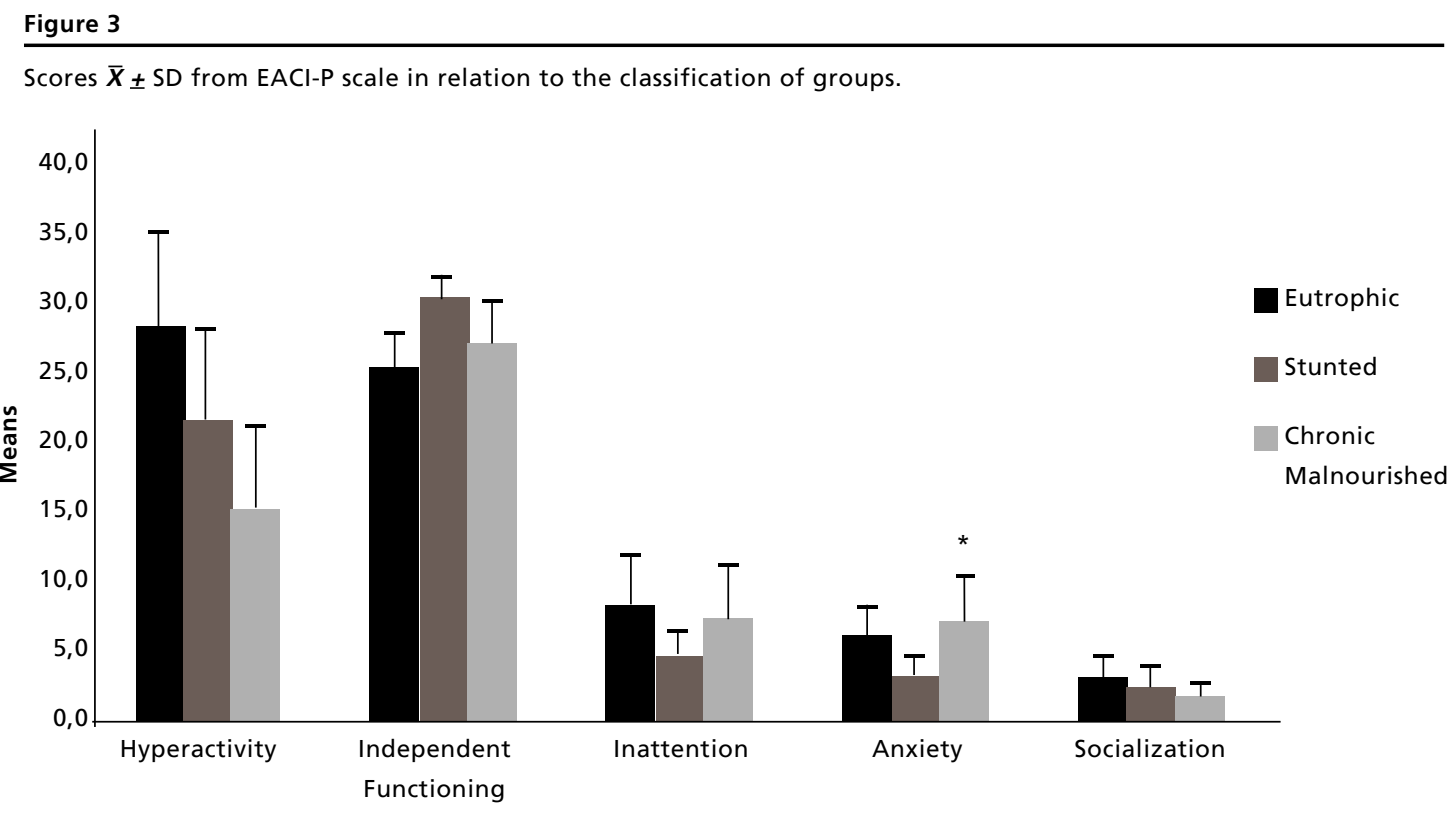

* Kruskall-Wallis $(\mathrm{H}=7.464 ; \mathrm{p}=0.02)$, multiple comparisons - chronic malnourished $>$ stunted $(p=0,006)$; eutrophic $=$ stunted $(p=0.174)$; eutrophic $=$ chronic malnourished $(p=0.10)$. 


\begin{tabular}{|c|c|c|c|c|c|}
\hline Neuropsychological Tests & $\begin{array}{l}\text { Independent } \\
\text { variables }\end{array}$ & Coefficients & $\begin{array}{r}\text { Standard } \\
\text { Errors }\end{array}$ & $p$-value & $\begin{array}{r}\text { Adjusted } \\
\mathbf{R}^{2}\end{array}$ \\
\hline Simbols Cancellation Test & Sex & 8.20 & 3.17 & 0.01 & 0.37 \\
\hline \multirow[t]{3}{*}{ (Omission) } & Father's Education & -1.40 & 0.57 & 0.01 & \\
\hline & Mother's Education & -1.86 & 0.83 & 0.03 & \\
\hline & Birth weight & -0.008 & 0.003 & 0.02 & \\
\hline Simbols Cancellation Test & Sex & 46.05 & 14.8 & 0.003 & 0.52 \\
\hline \multirow[t]{2}{*}{ Total Analysed } & Age & 30.09 & 7.89 & 0.001 & \\
\hline & Income per capita & 51.72 & 19.9 & 0.01 & \\
\hline \multirow[t]{2}{*}{ Vocabulary } & Age & 1.79 & 0.71 & 0.01 & 0.27 \\
\hline & Father's Education & 0.54 & 0.25 & 0.03 & \\
\hline \multirow[t]{2}{*}{ Bender Immediate Memory } & Age & -1.19 & 0.58 & 0.04 & 0.24 \\
\hline & Father's Education & -0.46 & 0.20 & 0.02 & \\
\hline \multirow[t]{2}{*}{ Bender Delayed Memory } & Age & -1.61 & 0.65 & 0.01 & 0.24 \\
\hline & Father's Education & -0.52 & 0.22 & 0.02 & \\
\hline Immediate Story Recall & Sex & -4.32 & 1.42 & 0.004 & 0.27 \\
\hline \multirow[t]{2}{*}{ Delayed Story Recall } & Sex & -4.04 & 1.40 & 0.006 & 0.27 \\
\hline & Father's Education & 0.49 & 0.25 & 0.05 & \\
\hline \multirow[t]{2}{*}{ Semantic Fluency - Fruits } & Age & 1.24 & 0.34 & 0.001 & 0.42 \\
\hline & Group & 2.59 & 0.82 & 0.003 & \\
\hline \multirow[t]{2}{*}{ Semantic Fluency - Animals } & Age & 0.98 & 0.03 & 0.001 & 0.55 \\
\hline & Group & 1.73 & 0.74 & 0.02 & \\
\hline EACIP - hyperactivity & Age & 0.49 & 0.22 & 0.03 & 0.21 \\
\hline EACIP - independent functioning & SRQ & -0.97 & 0.42 & 0.02 & 0.27 \\
\hline \multirow[t]{2}{*}{ EACIP- socialization } & Income per capita & 1.05 & 0.38 & 0.009 & 0.26 \\
\hline & Father's Education & -0.10 & 0.05 & 0.03 & \\
\hline
\end{tabular}

terms of neuropsychological tests (Table 3 ) significant differences between groups were found in the vocabulary test $\mathrm{F}(2,69)=3.19 ; \mathrm{p}=0.04$, the chronically malnourished group having performed more poorly than the other groups $\left(\mathrm{p}_{\mathrm{s}}<0.05\right)$. In addition, in the Corsi forward test $\left(\mathrm{X}^{2}(2)=6.80 ; \mathrm{p}=0.03\right)$ the chronically malnourished group had significantly lower scores than the stunted group $(\mathrm{p}=0.01)$; however, compared to the eutrophic group, no significant differences were found. One tailed t test comparing values to expected means ${ }^{30}(4.0 \pm 1.3)$ was undertaken and scores of the eutrophic group showed expected results in terms of norms for the age $(p=1.00)$ while there was a tendency $(p=0.07)$ of the chronically malnourished individuals to score below norms.

EACI-P scale results did not determine significant differences among groups in hyperactivity, independent functioning, inattention and socialization. In terms of anxiety, however, there was a significant difference $\left(\mathrm{X}^{2}(2)=7.464 ; \mathrm{p}=0.02\right)$ : the chronically malnourished had higher scores than the stunted individuals $(\mathrm{p}=0.006)$ and tended to be different in relation to the eutrophic group $(\mathrm{p}<0.10)$ (Figure 3).
Concerning regression analysis (Table 4) two variables of interest showed significant association: in the semantic memory test (animals and fruit) malnourished children had higher scores replicating what the ANOVA showed and weight at birth was significantly associated only with omissions in the cancellation test (smaller weight led to worse scores). The remaining associations in Table 4 will not be discussed as they are not relevant to the objective of the present study.

\section{Discussion}

Overall results of the present study determined that malnutrition can affect cognitive development, but this was observed in specific cognitive functions only and depended on the degree of malnutrition as previously shown. 5,9,11,12 Here chronic malnutrition led to lower scores in the vocabulary test (expressive speech), Corsi Block test - forward (visuospatial short-term memory), and higher scores in the anxiety factor of the behavioural scale, while the stunted group showed no impairment. This occurred despite the small sample size employed, indicating that these 
functions are very sensitive to nutritional status and must be further investigated.

In the present study only one child in the malnourished and one in eutrophic groups had birth weight below $2.5 \mathrm{~kg}$ so differences between groups cannot be ascribed to malnutrition in utero which is known to result in cognitive impairment.12-14 However, chronically malnourished children had significantly lower birth weighs when compared to the eutrophic group. We believe this was not responsible for differences between groups as the only significant correlation between birth-weight and performance occurred for a test in which no differences between groups were found (omissions in the cancellation test) and was also very low $(r=0.37)$. Furthermore, there is no evidence in the literature that weight at birth if higher than $2.5 \mathrm{~kg}$ is associated to cognitive development.

Impaired cognitive performance can also not be explained by socio-economic status because all children were equated in this respect, including parents' schooling levels. Additionally, none of the children had a history of long periods of hospitalization due to infection and/or diarrhoea, a factor also associated to major cognitive impairment.6,7,9,10,12,15,16,17 Furthermore, groups did not differ in terms of age and sex. Regarding the impact of malnutrition on the vocabulary test, which reflects expressive speech and the process of organized thinking through word definition, the literature is unclear. Some seem to believe that unfavourable environmental conditions impair the development of this cognitive function, 21 a hypothesis not confirmed by our results since eutrophic and malnourished children were equated in this respect. Contrarily, in support to our findings of lower scores in the chronically malnourished children, impairment in this function was demonstrated in children with severe malnutrition when compared to other individuals with the same background, ${ }^{9}$ suggesting that socio-economic status by itself does not determine cognitive function performance. Hence, our results suggest that even when environmental conditions are favorable, malnutrition can impair this function. ${ }^{9}$ Despite this, others have not found similar impairments with other, albeit similar, vocabulary test, ${ }^{7}$ possibly due to different measuring methods of this function.

In terms of the impairment of visual-spatial short-term memory in the chronically malnourished in relation to the stunted groups as measured by the Corsi (forward), it is important to mention that although no difference was observed between the chronically malnourished and the eutrophic groups, data of the latter showed normal results $(4.0 \pm 0.8)$ for this population in terms of estimated means and standard deviations, while those of the malnourished individuals were on the inferior limit $(3.7 \pm 0.6)$. In addition, results in this test can not be related to deficits in visual perception since the chronically malnourished group was not impaired in the naming subtest and Bender Test. Unfortunately there are no other studies in the literature investigating visuospatial working memory in malnourished children. Our data suggest that this function could be severely impaired by malnutrition, even in children living in favorable environmental conditions and must be further investigated. Lack of information concerning this function in previous studies reinforces the significance of taking into account widely accepted theories/models of memory and cognition (e.g., the existence of various components of working memory) when studying the impact of malnutrition on cognitive development.

In contrast to the results in the Corsi test, no impairment was found in corresponding verbal short-term memory (forward and backward digit span), as well as in pseudoword repetition. This differs from results of digit span impairment by malnutrition. 8,9,12 Bearing in mind the Agarwal et al. 12 assessed children with prenatal malnutrition and the remaining studies 8,9 did not report the children's weight at birth, it is possible that prenatal malnutrition is a key factor in determining major impairment in the development of this cognitive process. This would explain why no effect was observed in the present study considering, that in general, our sample did not have low birthweight.

It has been demonstrated that malnutrition risk could be related to maternal mental health and psychological/emotional factors, 18 -20 constituting one of the environmental factors perpetuating malnutrition. In the present study, the number of maternal psychiatric symptoms was not a problem in the malnourished and stunted groups but was unexpectedly larger in the eutrophic group, a fact that can be considered a limitation of this study. However, seeing that there was no correlation that approached significance between results in SRQ-20 and any of the tests applied here we believe that this finding has no implication on the overall results.

Regarding remaining cognitive functions evaluated, the conclusion was that attention, executive functions, verbal working memory, long-term memory and visuoconstructive functions were not impaired by malnutrition. It could be argued that this could be due to the small sample size. However, no 
such effects were also found using a means of increasing sample size, combining scores of both malnourished groups and contrasting them with those of the eutrophic children as in regression analysis. So the small sample size, may not have been responsible for lack of effects in these measures. Similar studies that did find this type of impairment 9,13 involved individuals with prenatal malnutrition, a variable that seems crucial in the determination of more severe change in cognitive development. ${ }^{12,13}$ Indeed, the strength of the present paper lies in the fact that despite the small sample size, cognitive effects of postnatal malnutrition were determined. Still, studies with larger samples must be carried out to investigate the specific functions affected, and to what extent, by pre- and postnatal malnutrition.

Finally, concerning child behaviour assessed by the teacher-rating scale, the chronically malnourished children showed higher levels of anxiety, confirming previous findings of motivational alterations related to malnutrition in humans 9,22 and animals.22,31 It is unknown whether such factors are related to changes in cerebral functioning or result from the interaction between malnutrition and environmental experience, affective and social deprivation. 22 Bearing this in mind, it is important to deter- mine more clearly the nature of emotional alterations in malnourished children, for cognitive tasks performance can be affected by anxiety and inattention. 22,31

In conclusion, visuospatial short-term memory, vocabulary, and anxiety, all impaired by malnutrition in this study even when environmental conditions were adequate for development, seem to be sensitive to chronic malnutrition and must be investigated in detail since they have major impact in the overall cognitive function. Apart from the constraints of the small sized sample, preservation of the remaining cognitive functions found here can also be credited to adequate environmental conditions under which children lived, as well as the fact that they were not characterized as having prenatal malnutrition, factors that may have reduced the malnutrition effects on the cognitive development.

\section{Acknowledgments}

To the parents and children for their participation, to Angela T. Paes for the statistical analysis, and the cooperation of the professionals at "Escola Prof. Homero dos Santos Fortes".

\section{References}

1. Almeida CA, Ricco RG. Avaliação do estado nutricional com ênfase à antropometria. Pediatria. (São Paulo) 1998; 20: 385-98.

2. Morgane PJ, Austin-Lafrance R, Bronzino J, Tonkiss J, DiazCintra S, Cintra L, Kemper T, Galler JR. Prenatal malnutrition and development of the brain. Neurosci Biobehav Rev. 1993; 17: 91-128.

3. Delong GR. Effects of nutrition on brain development in humans. Am J ClinNutr. 1993; Suppl. 57: 286S-290.

4. Nóbrega FJ, Campos ALR. Fraco vínculo mãe-filho como fator de risco. In: Nóbrega FJ, editor. Distúrbios da nutrição. Rio de Janeiro: Revinter 1998. p. 94-9.

5. Campana AP, Trindade CEP, Nóbrega, FJ, Goldberg TML, Jaehn SM, Miranda AFM, Pinho SZ. Análise do desempenho de escolares em teste psicométrico e sua relação com a condição nutricional. J Pediatr. (Rio J) 1992; 68: 338-41.

6. Galler JR, Ramsey FC, Forde V, Salt P, Archer E. Long-term effects of early kwashiorkor compared with marasmus. II. Intellectual performance. J Pediatr Gastroenterol Nutr. 1987; 6: 847-54.

7. Hoorweg J, Stanfield JP. The effects of protein energy malnutrition in early childhood on intellectual and motor abilities in later childhood and adolescence. Dev Med Child Neurol.1976; 18: 330-50.
8. Perales CG, Heresi E, Pizarro F, Colombo M. Estudio de funciones cognitivas en escolares de nivel intelectual normal com antecedentes de desnutrición grave y precoz. Arch Latinoam Nutr. 1996; 46: 282-6.

9. Upadhyay SK, Agarwal KN, Agarwal DK. Influence of malnutrition on social maturity, visual motor coordination and memory in rural school children. Indian J Med Res. 1989; 90: 320-7.

10. Vega-Franco L, Robles-Martínez B. Desarollo intelectual y crecimiento somático de escolares afectados por desnutrición a una edad temprana. Bol Méd Hosp Infant Méx. 1989; 46: 328-34.

11. Reyes MRL, Valdecanas CM, Reyes OL, Reyes TM. The effects of malnutrition on the motor, perceptual, and cognitive functions of Filipino children. Int Disabil Stud. 1990; 12: 131-6.

12. Agarwal KN, Agarwal DK, Upadhyay SK. Impact of chronic undernutrition on higher mental functions in Indian boys aged 10-12 years. Acta Paediatr. 1995; 84: 1357-6.

13. Jefferis BJMH, Power C, Hertzman C. Birth weight, childhood socioeconomic environment, and cognitive development in the 1958 British birth cohort study. BMJ. 2002; 325: 305-10. 
14. Trindade CEP, Nóbrega FJ. Caracterização do recémnascido desnutrido intra-uterino. In: Nóbrega FJ, editor Desnutrição intra-uterina e pós-natal. São Paulo: Panamed; 1986. p. 257-73.

15. Berkman DS, Lescano AG, Gilman RH, Lopez SL, Black MM. Effects of stunting, diarrhoeal disease, and parasitic infection during infancy on cognition in late childhood: a follow-up study. Lancet. 2002; 359: 564-71

16. Mendez MA, Adair LS. Severity and timing in the first two years of life affect performance on cognitive tests in late childhood. J Nutr. 1999; 129: 1555-62.

17. Islam MA, Rahman MM, Mahalanabis D. Maternal and socioeconomic factors and the risk of severe malnutrition in a child: a case-control study. Eur. J Clin Nutr. 1994; 48: 416-24.

18. Carvalhaes MABL, Benício MHA. Capacidade materna de cuidar e desnutrição infantil. Rev Saúde Pública. 2002; 36: 188-97.

19. Falcone VM. Disfunção familiar e baixa estatura em escolares da rede pública de ensino de São Paulo: estudo de caso-controle [dissertação mestrado]. São Paulo: Escola Paulista de Medicina da Universidade Federal de São Paulo; 2001.

20. Miranda CT, Turecki G, Mari JJ, Andreoli SB, Marcolim MC, Goihman S, Puccini R, Strom BL, Berlin JA. Mental health of the mothers of malnourished children. Int $\mathrm{J}$ Epidemiol. 1996; 25: 128-32.

21. Colombo M, Parra A, López I. Intellectual and physical outcome of children undernourished in early life is influenced by later environmental conditions. Dev Med Child Neurol. 1992; 34: 611-22.

22. Strupp BJ, Levitsky DA. Enduring cognitive effects of early malnutrition: a theoretical reappraisal. J Nutr. 1995; 125 2221S-2232

Submitted on December 6, 2005

Final version on December 7, 2006

Aproved on January 12, 2007.
23. Miranda MC, Muszkat M. Neuropsicologia do desenvolvimento. In: Andrade VC, Santos FH, Bueno OFA, editores. Neuropsicologia hoje. São Paulo: Artes Médicas; 2004. p 211-24

24. Sarni RS. Avaliação da condição nutricional: crianças e adolescentes/método antropométrico. Temas Nutr Pediatr. 2001; $1: 28-28$.

25. Lezak MD. Neuropsychological assessment. 3rd ed. New York: Oxford University Press; 1985.

26. Santos FH, Bueno OFA. Validation of the Brazilian children's test of pseudoword repetition in Portuguese speakers aged 4 to 10 years. Braz J Med Biol Res. 2003; 36: 153347.

27. Stein LM. Teste de desempenho escolar. São Paulo: Casa do Psicólogo; 1994.

28. Brito GNO. EACI-P - Escala de avaliação do comportamento infantil para o professor, manual. Rio de Janeiro: Entreletras; 1999.

29. Mari JJ, Willims P. A comparison of the validity of two psychiatric screening questionnaires (GHQ-12 and SRQ20 ) in Brazil, using relative operating characteristic (ROC) analysis. Psicol Med. 1985; 5: 651-59.

30. Santos FH, Mello CB, Bueno OF, Dellatolas G. Crosscultural differences for three visual memory tasks in Brazilian children. Percept Mot Skills. 2005; 101: 421-33.

31. Pollit, E. Developmental sequel from early nutritional deficiencies: conclusive and probability judgements. J Nutr 2000; 130 (Suppl): 350S-353. 